\title{
Smart Protective Clothing for Law Enforcement Personnel
}

\author{
Meike Reiffenrath ${ }^{1}$, Melanie Hoerr ${ }^{2}$, Thomas Gries ${ }^{3}$, Stefan Jockenhoevel ${ }^{4}$, \\ ${ }^{1-4}$ Institut für Textiltechnik - RWTH Aachen University, Germany
}

\begin{abstract}
Smart protective clothing is a promising niche for innovative products with great potentials on the textile and apparel market. Generally, smart textiles are defined as textile products with integrated, additional functions. These functions provide solutions for a wide variety of applications such as healthcare, sports, protective clothing and the automotive industry.

Smart protective clothing offers many possibilities to increase the safety of operations and reduce casualties. However, the integration of smart functions into protective clothing provides many challenges. The functions need to be fully integrated into the protective clothing, so that they do not result in a weakening of the armour.

The main goal of the European research project SmartPro is the development of lightweight and flexible protective clothing for security personnel with integrated smart functionalities. These include heart rate sensors, a damage control system and a geolocalisation module as well as wireless data transfer by means of textile antennas.
\end{abstract}

Keywords - Damage control, health monitoring, textile antennas, smart protective clothing.

\section{INTRODUCTION}

Nowadays, protective clothing for law enforcement personnel is mostly heavy, bulky and rigid. Therefore it limits the wearer's mobility and agility. Additionally the protective clothing only provides a limited protection against stabbing since it is mainly designed for protection against ballistic threats.

Protective clothing should prevent the penetration of bullets or stabbing attacks and simultaneously distribute the impact energy over a large area to reduce blunt trauma. In order to achieve this, body armours consist of up to 40 layers of fabric and are therefore mostly rigid, bulky and heavy (1). These characteristics limit the wearer's mobility and agility, which is critical in situations of attack.

The main goal of the European research project SmartPro, which started in April 2014, is the development of lightweight and flexible protective clothing for security personnel with integrated smart functionalities (2). The ballistic as well as the stab protection of the protective clothing will be improved. Moreover, the project aims to develop innovative solutions to protect vulnerable body parts additionally to the torso. In order to achieve these goals, woven as well as 3D-knitted fabrics with optimised composition and structure will be developed. These fabrics will be chemically treated in order to further enhance their efficiency.

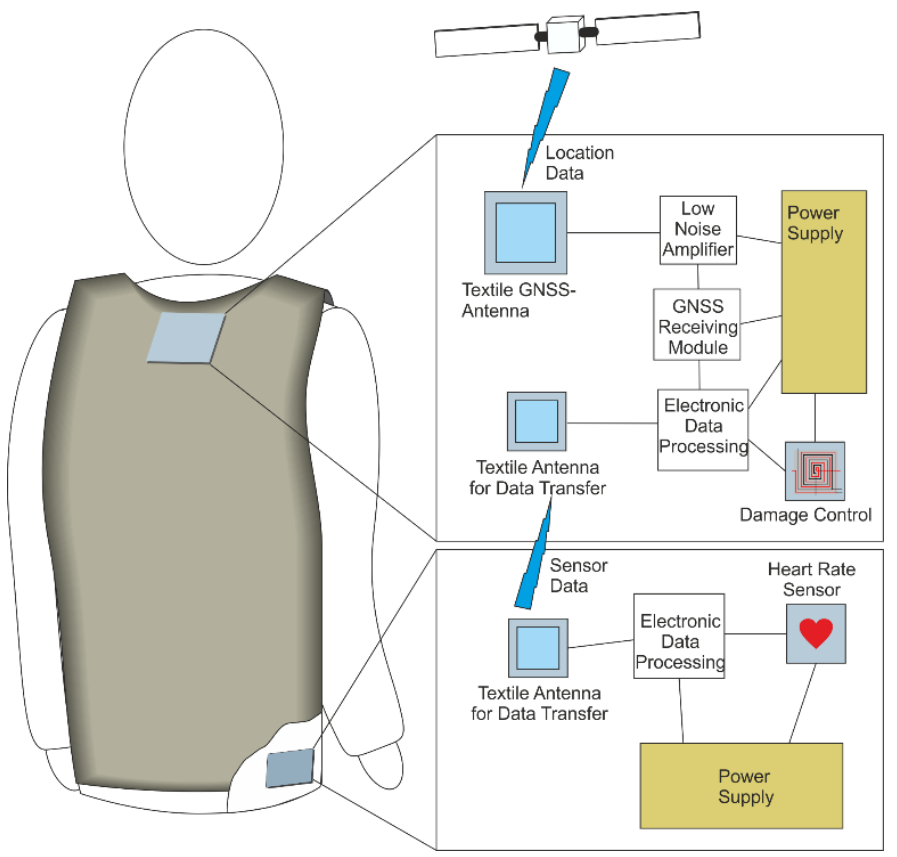

Fig. 1. Overview of the smart systems integrated into body armour. The picture gives a rough overview on the different modules of the smart system and their connections with each other.

Additionally smart functions for danger detection as well as textile antennas for geolocalisation and data transfer will be integrated into the protective clothing in order to increase the efficiency of the body armour even further. These smart functions include heart rate sensors, a damage control system and a geolocalisation module as well as gas sensors and wireless data transfer by means of textile antennas.

Fig. 1 shows an overview of the smart systems integrated into protective clothing for law enforcement personnel.

Smart protective clothing offers many possibilities to increase the safety of operations and reduce casualties. However, the integration of smart functions into protective clothing provides many challenges. The functions need to be fully integrated into the protective clothing, so that they do not result in a weakening of the armour.

Within SmartPro project, the Institute für Textiltechnik of RWTH Aachen University is responsible for the development of the smart systems described in the following sections.

\section{TEXTILE ANTENNAS}

Textile antennas offer many advantages for applications close to the human body: They are lightweight and can be easily 


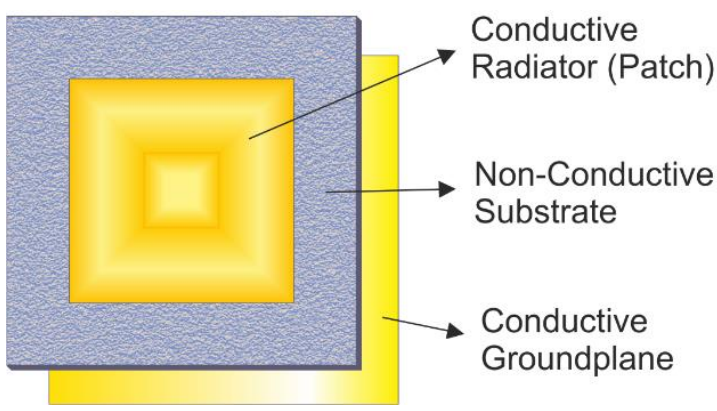

Fig. 2. Scheme showing the layered structure of a simple patch antenna. Patch antennas typically consist of two conductive layers used as groundplane and radiator and a non-conductive substrate as middle layer. The size and form of the radiator determines the antenna frequency, while the conductive groundplane shields the body from radiation and increases the directivity of the antenna.

integrated into clothing. Nevertheless, the possible deformation of the textile antenna might result in a shift of the resonance frequency, which will lead to a decrease in antenna performance.

Textile antennas can have different topologies such as patch antennas, dipoles or more complex structures, such as fractal antennas or antennas using electromagnetic bandgap structures. These different topologies are compared and evaluated in order to find the most suitable topology for use within SmartPro project.

The antenna form best suited for the use in on-body applications is the patch antenna (Fig. 2). Patch antennas have a planar structure and minimize radiation in the direction of the body due to the conductive groundplane (3). Additionally there are many different variations of the basic patch antenna, which allow to influence the antenna parameters, such as the antenna gain, the directivity or the radiation pattern.

Due to the advantages stated before, patch antennas are the chosen topology for the textile antennas developed within SmartPro project. Different materials, feeding technologies, geometries as well as different production technologies will be evaluated in order to achieve maximum performance while keeping the manufacturing process of the protective clothing as efficient as possible.

\section{A. Textile Antennas for Geolocalisation}

Geolocalisation is the identification of the position of a person or an object using the Global Navigation Satellite System (GNSS). Probably the best known GNS-System is the American system called GPS (Global Positioning System). However, there are also several other systems, such as GLONASS (Russian Federation), Galileo (European Union) or Beidou (China). Therefore the general term GNSS will be used within this article.

Especially in the case of injured law enforcement personnel it is important to be able to locate the injured. The geolocalisation via GNSS allows locating of law enforcement personnel during operations. Thereby supporting personnel may reach injured personnel faster, which leads to reduced casualties.
Textile antennas for geolocalisation using the GNSS will be integrated into the armour. In recent years many research was conducted in the area of textile antennas in general. However, the integration of textile antennas into protective clothing is challenging in terms of maintaining the required protection level.

The main advantage of planar, textile antennas, such as patch antennas for the use in a GNSS-receiver is the possibility to integrate the antenna smoothly into the outmost layer of the garment in order to achieve the best reception. Furthermore, the antenna can be integrated on the shoulder or upper back to provide a direct line of sight between the GNSS satellites and the antenna.

\section{B. Textile Antennas for Data Transfer}

One of the challenges in the development of smart clothing is the transfer of the data acquired by sensors. This can be done by integrating wires or wirelessly by the use of antennas. The wireless solution is preferable due to the better integration, especially with the use of textile antennas.

Within SmartPro there are two different kinds of wireless data transfer necessary. The first is the data transfer within the personal network (Body Area Network - BAN) of each individual. As depicted in Fig. 1, the data measured by the heart rate sensor needs to be transferred from the tight-fitting shirt worn underneath the body armour to the data processing unit within the armour itself. The second kind of data transfer is the transfer of data to a remote location such as an operations centre.

Possible technologies for the data transfer within the BAN are Bluetooth, RFID or the use of other frequencies within the ISM-Band (Industrial, Scientific and Medical Band). The use of textile antennas at frequencies around $2.4 \mathrm{GHz}$ for data transfer within body area networks has been widely studied in recent years. For the data transfer to the operations centre the most logical choice is the use of the TETRA band (Terrestrial Trunked Radio) which is the standard used by most emergency services within Europe.

The data that needs to be transferred includes the positioning data received by the GNSS module as well as the sensor data of the heart rate sensor and the damage control system. These sensors will be described in more detail in the next sections.

\section{TEXTILE SENSORS}

Textiles are considered as "smart textiles" when they include additional functions such as sensors or actuators. While textile antennas offer a possibility to transfer data within Body Area Networks as well as towards external devices, the data itself needs to be acquired by sensors.

Textile sensors offer a high grade of integration into textiles. They can be implemented by different textile technologies, such as weaving, knitting, printing or embroidery. The integration of health monitoring functions into protective clothing ensures the safety of law enforcement personnel and allows faster reaction times for the support and rescue of injured persons. 


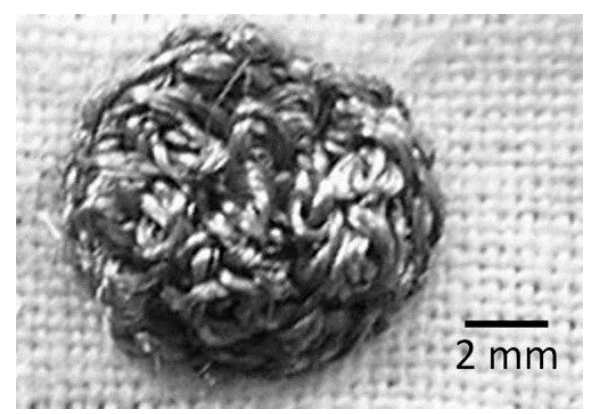

Fig. 3. Textile electrode obtained by moss embroidery technology.

\section{A. Health Monitoring System}

In wearable applications, textile electrodes are an advantageous solution for the measurement of biosignals due to their flexibility and textile haptic perception. Textile electrodes can be integrated into tight-fitting clothing with direct skin contact, e.g. a shirt. Such electrodes can be implemented by technologies, such as knitting, weaving, embroidery or printing.

Within SmartPro project, textile electrodes are investigated for the measurement of the heart rate as one of the most important biosignals. The textile production technology chosen for the sensors is embroidery.

Embroidery can be used to apply a yarn to a textile substrate in a pre-defined geometry. There are three different kinds of embroidery methods available: standard embroidery, chain stitch embroidery and tailored fibre placement (TFP). Moss embroidery is a form of chain stitch embroidery and is particularly interesting for the creation of textile sensors. The three-dimensional structure achieved by moss embroidery with conductive yarn, which can be seen in Fig. 3 provides better skin contact than flat embroidered electrodes produced by standard embroidery. Electrodes of this kind can be used as sensor electrodes for body signal monitoring such as Electrocardiography (ECG), Electroencephalography (EEG) or Electromyography (EMG).

The data acquired by the sensors will be processed by a data processing unit and transferred via textile antennas (see chapter II).

\section{B. Damage Control System}

Textile sensors for structural health monitoring are an important research area; nevertheless there is a lack of solutions for the monitoring of clothing. During operations it is necessary to detect and identify threats to law enforcement personnel. The newly developed damage control system ensures a timely detection of attacks on law enforcement personnel.

The damage control system will be applied to the protective clothing as an embroidered matrix-structure using the tailored fibre placement (TFP) technology. This technology allows for a continuous placement of a selected fibre or wire on a textile substrate. This fibre or wire is affixed to the substrate by an upper and a lower stitching thread.

For the damage control system a conductive wire will be applied to the textile substrate in a matrix structure, which will detect damage by ballistic or stabbing attacks. Furthermore, the damage control system will locate the injury regarding the main organs as shown in Fig. 4.

Different measurement concepts as well as sensor designs will be investigated and evaluated according to the different scenarios of possible attacks. The sensor concepts include single sensors as well as sensor arrays (see Table I). For a single sensor, every single sensing point is connected to an evaluation unit by its own wire. In case of damage to the sensor, the resistance of this sensor changes and the damaged sensor can be located by a monitoring of all sensors. For a sensor array, each sensing point is connected with two wires. One wire is connected to the neighbouring sensors in $x$-direction and one wire is connected to neighbouring sensors in $y$-direction. In case of damage to the sensor, the resistance of each wire in $x$ - and $y$ direction changes and the damaged sensor can easily be located by calculating the intersection of both wires.

Conductive materials for the damage control sensors can be wires or conductive threads. First prototypes have been obtained with lacquered copper wire with a cross section of $0.2 \mathrm{~mm}^{2}$.

The sensor matrix can be applied either in a single layer or in an arrangement of multiple layers. The arrangement of multiple layers increases the resolution of the damage control system. The sensing elements will be placed so that the damage can be assigned to the main organs as shown in Fig. 4. This information can help to assess the severity of injuries to law enforcement personnel.

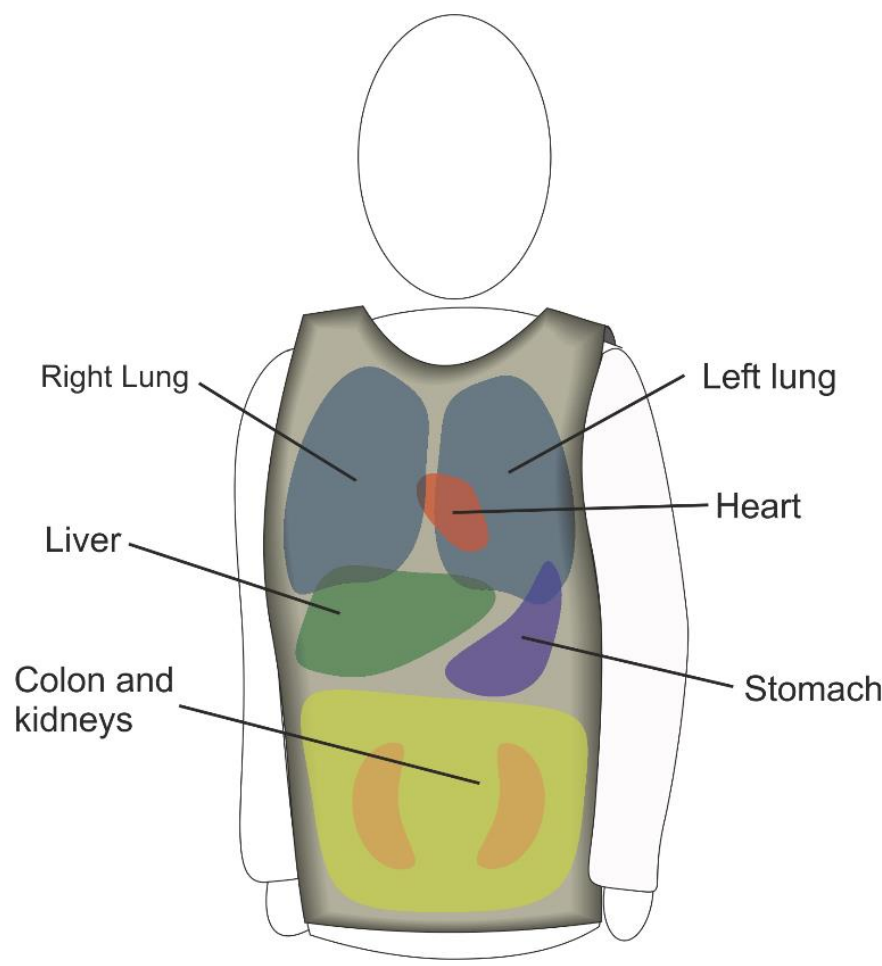

Fig. 4. Overview of the position of the main organs: This information is used to locate and assess possible injuries of law enforcement personnel during operation. 
TABLE I

SENSOR CONCEPTS FOR THE DAMAGE CONTROL SYSTEM

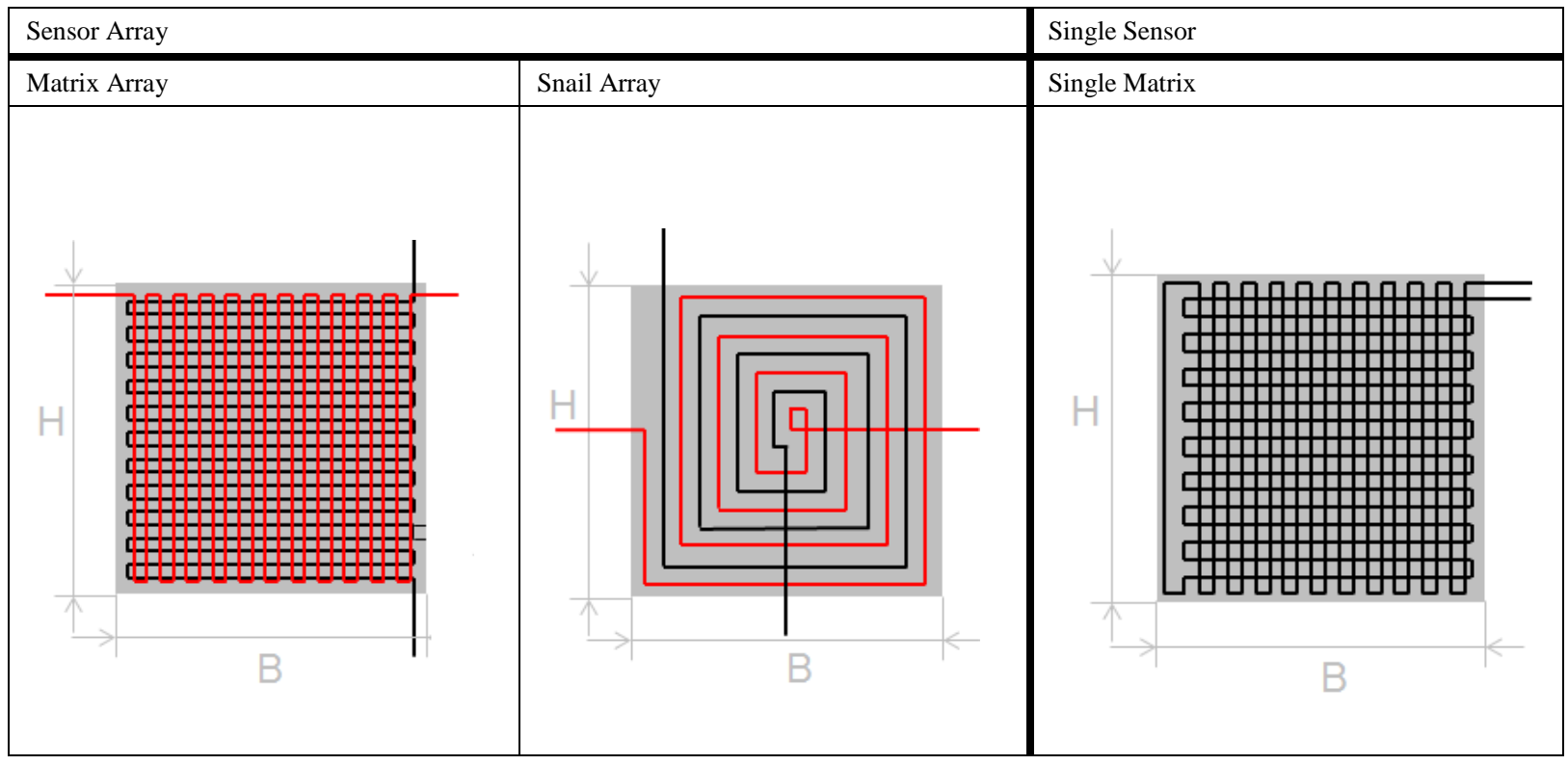

\section{RESULTS}

Protective clothing for law enforcement personnel is mostly heavy, bulky and rigid. Therefore it is uncomfortable to wear and limits the wearer's mobility and agility. Additionally the protective clothing only provides a limited protection against stabbing since it is mainly designed for protection against ballistic threats.

The research within SmartPro project will result in solutions for lightweight, flexible and smart protective clothing for law enforcement personnel. The ballistic as well as the stab protection of the protective clothing will be improved.

The Institut für Textiltechnik is responsible for the development and integration of smart functions into the protective clothing. These smart functionalities include textile sensors to measure biosignals, such as the heart rate, a damage control system and a geolocalisation module as well as wireless data transfer by means of textile antennas.

The smart functions integrated into the protective clothing can also be used for other applications, such as outdoor clothing and the health monitoring of athletes or elderly patients.

\section{ACKNOWLEDGEMENT}

The research leading to these results has received funding from European Community's Seventh Framework Programme (FP7) under Grant Agreement N 607295.

\section{REFERENCES}

1. Dilva, E. Protective clothing for law enforcement personnel. In: Protective and Comfort Science. 2005

2. SMARTPRO. Lightweight, flexible and smart protective clothing for law enforcement personnel [online]. [Accessed 15.10.2014.]. Available from: http://smartpro-project.eu

3. Hertleer, C. Design of planar antennas based on textile materials. Ph.D. thesis. Ghent.: Ghent University, 2009

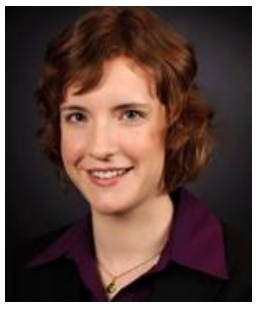

Meike Reiffenrath, Dipl.-Ing., is a PhD student at Institut für Textiltechnik of RWTH Aachen University, Germany. She received her diploma degree in Mechanical Engineering from RWTH Aachen University in 2014.

She is currently working as a research assistant in the area "Medical Textiles" at the Institut für Textiltechnik, RWTH Aachen University. Her main research interests in the research group "Medical Smart Textiles" include textile antennas for body-centric communication and geolocalisation as well as textile integrated pressure measurement.

Address: Institut für Textiltechnik of RWTH Aachen University, OttoBlumenthalstr. 1, 52074 Aachen, Germany.

E-Mail: meike.reiffenrath@ita.rwth-aachen.de

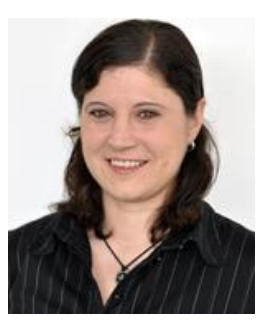

Melanie Hoerr, Dipl.-Ing., is a PhD student at Institut für Textiltechnik of RWTH Aachen University, Germany. She received her diploma degree in Mechanical Engineering from RWTH Aachen University in 2010 after finishing her training as industrial mechanic (specialty operating technology).

Since 2011, she is as a research assistant in the area "Medical Textiles" at the Institut für Textiltechnik, RWTH Aachen University. She is the head of the research group "Medical Smart Textiles". Her main research interests include textile sensors and actuators for medical applications as well as embroidery technology with a focus on embroidered electrodes for the monitoring of bodily functions.

Address: Institut für Textiltechnik of RWTH Aachen University, OttoBlumenthalstr. 1, 52074 Aachen, Germany.

E-Mail: melanie.hoerr@ita.rwth-aachen.de 


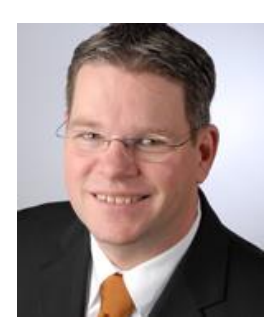

Stefan Jockenhoevel, Univ.-Prof. Dr. med., is a professor at the Helmholtz Institute Aachen and the Institut fuer Textiltechnik of RWTH Aachen University, Germany. In 1995 he graduated in Medicine from RWTH Aachen University and started his clinical practice in Thoracic \& Cardiovascular Surgery at the Heart Centre Baden, followed by positions at the University Hospital Aachen, the University Hospital in Zurich, and later as a senio physician at the Institute National de Chirurgie

Cardiaque, Luxembourg.

Since 2011 he is holding the transfaculty professorship for Tissue Engineering \& Textile Implants, heading the Division of Tissue Engineering \& Biomaterials at the Helmholtz Institute Aachen (Medical Faculty) and the Division of Life Science \& Smart Textiles at the Institut fuer Textiltechnik (Faculty of Mechanical Engineering) of RWTH Aachen University.

Address: Institut fuer Textiltechnik of RWTH Aachen University, OttoBlumenthalstr. 1, 52074 Aachen, Germany.

E-mail: stefan.jockenhoevel@ita.rwth-aachen.de

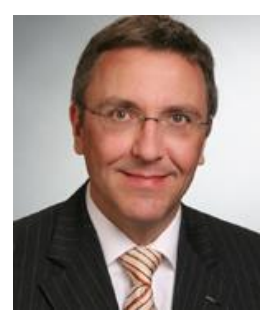

Thomas Gries, Univ.-Prof. Prof. h.c. Dr.-Ing. Dipl.Wirt. Ing., studied Mechanical Engineering at RWTH Aachen University. In 1992 he received a degree in Economic Engineering studies in parallel to his $\mathrm{PhD}$ studies. After achieving the Dr.-Ing. degree in Mechanical Engineering in 1995, he worked at the Department of Technologies for Fibres at Lurgi Zimmer AG at an international level.

Since 2001 Prof. Gries is director of the Institut fuer Textiltechnik of RWTH Aachen University. He coordinates and consults multi-disciplinary research activities and projects. Additionally to his research and administrative activities at the Institut fuer Textiltechnik of RWTH Aachen University, Prof. Gries takes a number of honorary positions and superior duties such as being a spokesman and chairman at scientific forums, events and communities. In March 2013 he was granted with an honourary professorship at the Lomonosov Moscow State University. Address: Institut fuer Textiltechnik of RWTH Aachen University, OttoBlumenthalstr. 1, 52074 Aachen, Germany.

E-mail: thomas.gries@ita.rwth-aachen.de

\section{Meike Reiffenrath, Melanie Hoerr, Thomas Gries, Stefan Jockenhoevel. Viedais aizsargapgēēbs tiesībsargājošo iestāžu darbiniekiem}

Mūsdienu tiesībsargājošo iestāžu darbinieku aizsargapgèerbs lielākoties ir smags, apjomīgs un neelastīgs. Tas ierobežo valkātāja kustības un samazina veiklību. Turklāt tam ir ierobežota valkātāja aizsardz̄̄ba pret caurduršanu, jo tas galvenokārt ir paredzēts aizsardzībai pret ballistisko apdraudējumu. Eiropas Savienības 7tās ietvara programmas (FP7-SEC-2013-1) (granta finansējuma līgums Nr. 607295) finansētā pētniecības projekta SMARTPRO galvenais mērkis ir izstrādāt tiesībsargājošo struktūru personālam paredzētu vieglu un elastīgu aizsargapgèèrbu ar integrētām viedajām aizsargfunkcijām. Ballistiskā aizsardzība, kā arī caurduršanas aizsardzība tiks pilnveidota. Papildus apdraudējuma noteicējs un tekstila antena tiks integrēta aizsargapgèrbā. RWTH Āhenas universitātes Tekstiltehnikas institūts ir atbildīgs par šādu viedo funkciju izstrādi un integrēšanu. Viedajās funkcijās paredzēts ieklaut sirdsdarbības noteicēja sensoru un bruṇuvestes strukturālos monitoringa sensorus, piemēram, ğeolokalizācijas tekstila antenas un datu pārraidīiāju.

Tiesību aizsardzības iestāžu personāla veselības monitoringa funkciju integrācija aizsargapgeērbā sniedz drošību un lauj saīsināt ievainotajai personai nepieciešamo atbalsta sniegšanas un glābšanas laiku. Kamēr tiesībsargājošo iestā̌̌u personāla operatīvo darbību laikā sensori noteiks iespējamo apdraudējumu, tekstila antenas tiks izmantotas attiecīgo datu pārraidei uz operatīvās darbības vadības centru, nodrošinot nepieciešamo rīcību.

Pētijjuma SMARTPRO ietvaros tiks radīts risinājums vieglam, lokanam un viedam tiesībsargājošo iestāžu personāla aizsargapǵērbam. Aizsargapǵērbā integrētajām viedajām funkcijām var tikt atrasts cits pielietojums, piemēram, virsdrēbēs vai vecāka gadagājuma pacientu veselības monitoringam.

Мейке Рейффенратх, Мелание Хоерр, Тхомас Гриес, Стефан Йоцкенхоевел. Умная защитная одежда для сотрудников правоохранительных органов

В настоящее время защитная одежда для сотрудников правоохранительных органов является, в основном, тяжелой, громоздкой и жесткой. Поэтому она ограничивает мобильность и ловкость пользователя. Кроме того, она обеспечивает только ограниченную защиту от проколов, так как она в основном предназначена для защиты от баллистических угроз. Основная цель Европейского исследовательского проекта SmartPro является развитие легкой и гибкой защитной одежды для сотрудников службы безопасности с интегрированными Умными-интеллектуальными функциями. Баллистическая защита, а также защита от проколов для защитной одежды будет улучшена. Кроме того в защитной одежде будут интегрированы умные функции для обнаружения опасности и текстильные антенны. Институт Fuer Textilotechnik из Университета Аахена является ответственным за разработку и интеграцию следующих умных функций. Они включают в себя датчик сердечного ритма и датчик для структурного мониторинга брони, а также текстильные антенны для геолокализации и передачи данных.

Интеграция функций мониторинга здоровья в защитной одежды обеспечивает безопасность сотрудников правоохранительных органов и позволяет уменьшить время реакции для поддержки и спасения пострадавших. В то время как датчики обнаружения будут улавливать возможные опасности для сотрудников во время работы правоохранительных органов, текстильные антенны будут использоваться для передачи соответствующих данных в оперативный центр, чтобы обеспечить немедленное действие.

Исследования в рамках проекта SmartPro приведет к решению по созданию легкой, гибкой и умной защитной одежды для сотрудников правоохранительных органов. Умные функции, интегрированные в защитной одежды, могут быть также использованы для других целей, таких как верхняя одежда и контроль за состоянием здоровья пациентов пожилого возраста. 